УДК $633.522+543.544$

${ }^{[0000-0001-7511-5126]}$ С. В. Шкурдода ${ }^{1}$, завідувач відділу досліджень матеріалів, речовин та виробів, e-mail: sergeyshkur@yahoo.com

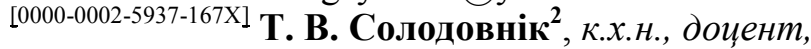

e-mail: solodovniktetana@gmail.com

${ }^{[0000-0002-8026-1483]}$ В. В. Пасічник ${ }^{1}$, заступник завідувача сектору досліджень, ${ }^{[0000-0002-5253-232 X]}$ К. П. Король ${ }^{\mathbf{1}}$, завідувач сектору досліджень,

${ }^{[0000-0003-1400-6131]}$ Д. Ю. Шинкаренко ${ }^{1}$, головний судовий експерт

${ }^{1}$ Черкаський науково-дослідний експертно-криміналістичний центр МВС

вул. Пастерівська, 104, м. Черкаси, 18000, Україна

${ }^{2}$ Черкаський державний технологічний університет

б-р Шевченка, 460, м. Черкаси, 18006, Україна

\title{
МЕТОДИКИ ВИЗНАЧЕННЯ ВМІСТУ А9-ТЕТРАГІДРОКАНАБІНОЛУ В НАСІННІ КОНОПЕЛЬ МЕТОДОМ ГАЗОВОЇ ХРОМАТОГРАФІЇ: АНАЛІЗ І НАУКОВЕ ОБГРУНТУВАННЯ
}

У статті піддаються предметному аналізу методики рідинно-рідинної екстракиії $\Delta-9$-ТГК з конопляного насіння з подальшою їх апробачією й удосконаленням для відділення

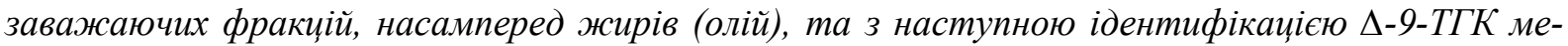
тодом газової хромато-мас-спектрометрї з мас-селективним детектуванням. Апробовано деякі методи рідинно-рідинної екстракиії конопляного насіння. Отримані результати дослі-

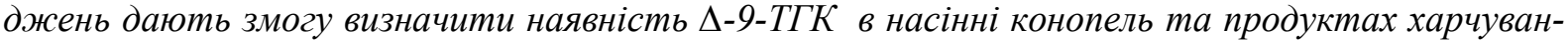
ня, виготовлених з насіння конопель. Встановлено, щчо метод екстракиії ацетонітрилом з подальшим промиванням гексаном є найбільш ефективним і легко відтворюваним та може бути

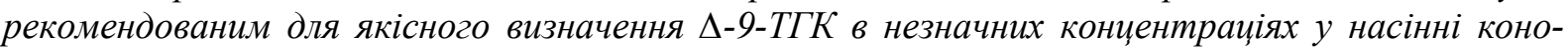
пель. Дані дослідження надалі можуть бути використані для кількісного визначення $\Delta-9-T Г К ~$ в насінні конопель та продуктах харчування, виготовлених з насіння конопель, із подальшим визначенням межі детектування (LOD) та межі кількісного виявлення (LOQ) зазначеної речовини, щчо необхідно для подальшої сертифікаиії иієї продукиії та ї̈ експорту.

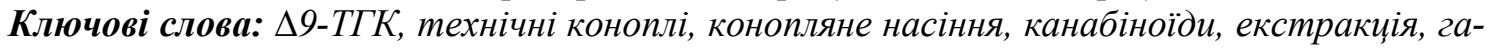
зова хромато-мас-спектрометрія.

Вступ. Коноплі (Cannabis sativa L) як одна 3 найдавніших і широко поширених рослин є важливим складником добробуту населення впродовж багатьох століть завдяки специфічним біологічним особливостям цієї луб'яної, олійної культури та унікальним споживчим властивостям конопляної продукції. Разом $з$ тим рослини конопель також відомі як лікарські і наркотичні рослини.

До особливостей видільної системи конопель відноситься їх спроможність виведення волосками назовні рослин секретів, які, в свою чергу, містять канабіноїди - групу терпенфенольних сполук, що $є$ похідними 2-заміщеного 5-амілрезорцину. До складу конопель входить близько 100 різних канабіноїдів [1], які поділяють на кілька типів (канабігероли, канабіхромени, канабідіоли, тетрагідроканабіноли, канабіельзони, ізотетрагідроканабіноли, канабіциклоли, канабі- тріоли) [2]. Однак до основних канабіноїдів відносять лише декілька, зокрема: тетрагідроканабінол (ТГК), канабінол (КБН), канабідіол (КБД), канабігерол (КБГ), канабіхромен (КБХ) та відповідні їм кислоти - тетрагідроканабінолова (ТГКК), канабінолова (КБНК), канабідіолова (КБДК), канабігеролова (КБГК), канабіхроменова (КБХК) [3, 4].

Психотропний ефект наркотичного засобу канабісу є результатом комплексної дії всіх канабіноїдів, хоча лише деякі з них мають психотропну дію в чистому вигляді. До них належить, насамперед, дельта-9-тетрагідроканабінол ( $\Delta-9-$ ТГК), що має основну психотропну дію і здатний селективно зв'язуватися в певних структурах головного мозку з канабіноїдними рецепторами. Такі основні канабіноїди, як КБД, КБН, КБХ, КБГ, самі по собі не мають психотропної дії, проте здатні вносити деякі доповнення в психотропну дію ТГК. 
Враховуючи психотропний ефект $\Delta-9$ ТГК, вирощування технічних конопель у більшості країн світу потрапляс під певні види ліцензування та регулюється відповідними державними органами відповідних країн, у тому числі й в Україні.

Так, відповідно до ст. 7 Закону України від 15.02.1995 № 60/95-ВР «Про обіг в Україні наркотичних засобів, психотропних речовин, їх аналогів і прекурсорів» (у редакції Закону України від 22.12.2006 № 530-V) заборонено культивування, використання або реалізацію рослин, які входять до переліку наркотичних засобів, психотропних речовин i прекурсорів, затвердженого Постановою Кабінету Міністрів України від 06.05.2000 № 770, що містить низький вміст наркотичних засобів для промислових цілей, виняток становить виробництво або виготовлення наркотичних засобів і психотропних речовин, яке можуть здійснювати підприємства всіх форм власності за наявності у них ліцензії на здійснення відповідних видів діяльності. Гранично допустимий вміст тетрагідроканабінолу у рослинах конопель установлюється Кабінетом Міністрів України за поданням спеціально уповноваженого органу виконавчої влади в галузі охорони здоров'я.

Для промислових цілей культивування рослин конопель, за винятком виробництва та виготовлення наркотичних засобів і психотропних речовин, на сьогоднішній день допускається, якщо насіння зібране 3 тих сортів рослин, у висушеній соломі яких вміст тетрагідроканабінолу не перевищує $0,08 \%$. В деяких інших країнах ця цифра коливається в межах від 0,2 до 0,3\% [5].

Незважаючи на психотропний ефект $\Delta$ 9-ТГК, потреба в продукції коноплярства дотепер не втрачає свою актуальність.

Гігієнічне природне волокно конопель за своїми властивостями переважає синтетичне волокно в багатьох галузях народного господарства [6]. Волокно конопель дуже міцне, повільно піддається гниттю, довго зберігає свої властивості при експлуатації у морській воді та інших агресивних середовищах, завдяки чому широко використовується для виготовлення різних виробів промисловості високої надійності та для виготовлення одягу, взуття і текстильних виробів.

Особливим попитом на ринку користується конопляне насіння як продовольчий товар. Використовують насіння також як посів- ний матеріал, на кормові цілі для худоби та птиці, для виготовлення приманок для риб і як харчовий продукт для людини.

Останнім часом конопляне насіння відносять до категорії «суперїжі» (superfood) природної сировини рослинного походження, яка відзначається підвищеним вмістом білків, вітамінів, мінералів, незамінних кислот, антиоксидантів, інших корисних речовин, воно має мінімум калорій і застосовується як біологічно активна добавка до їжі для здорового харчування людини $[7,8]$.

До складу конопляного насіння входять 25-35\% олії, 20-25 \% білків, 20-30 \% вуглеводів, 10-15\% клітковини, ненасичені жирні кислоти (Омега-3, -6, -9), незамінні амінокислоти, вітаміни, макро- та мікроелементи [710]. Обрушене насіння (після відділення оболонки) містить у середньому $46,7 \%$ олії та $35,9 \%$ білків [7]. Концентрація антинутріснтів, таких як фітинова кислота, таніни та інгібітори трипсину, в конопляному насінні дуже низька, що, в свою чергу, зумовлює високу засвоюваність корисних речовин [11]. У насінні конопель виділено такі найважливіші кислоти: насичені - пальмітинова, стеаринова, арахінова, бегенова; ненасичені - лінолева (Омега-6), олеїнова (Омега-9), альфа-ліноленова (Омега-3), гамма-ліноленова [6-8]. Співвідношення лінолевої (Омега-6) до альфаліноленової кислоти (Омега-3) в середньому становить 2, $0: 1 \div 3,7: 1$, що відповідає вимогам Всесвітньої організації охорони здоров'я Організації Об'єднаних Націй (BOO3 ООН) для забезпечення організму людини ненасиченими жирними кислотами (ННЖК) [7-9].

Враховуючи високу біологічну і харчову цінність, 3 насіння конопель виготовляють обрушене конопляне насіння, конопляну олію, конопляне борошно, висівки конопляні (клітковина), конопляний протеїн, навіть дитяче харчування - замінник молока.

В результаті постійно зростаючого споживання харчових продуктів 3 насіння конопель, зокрема олії, були деякі повідомлення про те, що прийом конопляної олії може спричинити позитивний наркотичний тест на вживання канабісу [12-15]. Дослідження, проведені 3 цього питання різними науковцями, показали, що насіння справді може містити $\Delta-9-\mathrm{TГК}$ у широкому діапазоні концентрацій [15-23]. Водночас концентрація $\Delta-9-\mathrm{TГK}$ коливається залежно від того, 3 технічних чи медичних конопель зібрано урожай. Так, у конопляному

(ㄷ С. В. Шкурдода, Т. В. Солодовнік, В. В. Пасічник, К. П. Король, Д. Ю. Шинкаренко, 2021 DOI: $10.24025 / 2306-4412.1 .2021 .230000$ 
насінні технічних сортів концентрація $\Delta-9$-ТГК може коливатися від 0 до 12 мкг/г, а в сортах медичних конопель 3 високим вмістом $\Delta$-9-ТГК - від 35,6 до 124 мкг/г [23].

Відомо, що на сучасному етапі розвитку у виробництві конопель України відбуваються процеси трансформації до ринкових умов, а також процеси та періоди становлення, що пов'язано зі збільшенням посівних площ технічних конопель і збільшенням обсягів виробництва лубоволокнистої сировини. Останнім часом наукові установи активізують селекцію та впроваджують на підприємствах новітні технології переробки насіння конопель у харчові оздоровчі продукти та парфумернокосметичні препарати. В зв'язку з цим виникає необхідність у вдосконаленні та розробці ефективних, простих у використанні та надійних методик екстракції й ідентифікації $\Delta$-9-ТГК в конопляному насінні та відповідній харчовій продукції з нього (обрушеному конопляному насінні, конопляній олії, конопляному борошні, клітковині, конопляному протеїні).

Метою дослідження $є$ аналіз наявних методик рідинно-рідинної екстракції $\Delta$-9-ТГК 3 конопляного насіння 3 подальшою їх апробацією й удосконаленням для відділення заважаючих фракцій, насамперед жирів (олій), та 3 наступною ідентифікацією $\Delta$-9-ТГК методом газової хромато-мас-спектрометрії з масселективним детектуванням.

Матеріали, інструменти та методики дослідження. Об'єктом дослідження було конопляне насіння врожаю 2020 р., зібране 3 технічної коноплі сорту «Гляна», культивованого з рослин роду коноплі для промислових цілей, що допускається законодавством України відповідно до [24], тобто зібраного із сортів рослин конопель, у висушеній соломі яких вміст $\Delta-9$-ТГК не перевищує $0,08 \%$.

Як стандарт використовували розчин $\Delta$-9-ТГК в етанолі концентрацією $5 \mathrm{m \Gamma} / \mathrm{cm}^{3}$ виробництва фірми Lipomed AG (LOT: 135.1B70.0L6.), який додатково розводили етанолом до концентрацій $1 \mathrm{мг} / \mathrm{cm}^{3}$ і $0,1 \mathrm{Mг} / \mathrm{cm}^{3}$.

Для ідентифікації $\Delta$-9-ТГК використовували газовий хроматограф Agilent Technologies 6890N (ГХ) з мас-селективним детектором Agilent Technologies 5975B (МСД). Хроматографічна колонка J\&W, HP$5 \mathrm{MS}(30,0$ м х 0,25 мм· х 0,25 мкм). Температурна програма термостата: початкова температура $-200{ }^{\circ} \mathrm{C}$ (1 хв.) і поступовий підйом температури зі швидкістю $25^{\circ} \mathrm{C} /$ хв до $280{ }^{\circ} \mathrm{C}$ (8 хв.). Режим вводу проби: $з$ поділом потоку (Split 5:1). Газ-носій - гелій. Об’єм проби 2 мкл. Режим роботи МСД - за повним йонним струмом (SCAN).

Для здійснення процесу екстракції та центрифугування 3 подальшою фільтрацією використовували ультразвукову ванну (УЗВ) і центрифугу ОПн-8.

Для приготування розчинів та для виконання аналізу використовувався стандартизований скляний мірний посуд.

В процесі пробопідготовки досліджуваного конопляного насіння використовували методику цільової екстракції $\Delta-9$-ТГК з метою відділення та ізолювання речовин (насамперед жирів), які можуть заважати дослідженню. Для кожного методу були попередньо підготовлені два зразки насіння (А і В). Зразок А - вихідне конопляне насіння, зразок В - конопляне насіння зі штучно внесеною кількістю стандартного розчину $\Delta-9-$ ТГК (в перерахунку на масу - 20 мкг).

Виклад основного матеріалу. В роботі було проведено дослідження за чотирма методами якісного виявлення $\Delta-9$-ТГК в конопляному насінні рідинно-рідинною екстракцією та порівняння ефективності і зручності їх застосування в професійних лабораторіях профільного призначення на основі аналізу хроматограм, отриманих методом газової хроматографії з мас-селективним детектуванням. На базі лабораторії відділу дослідження матеріалів, речовин і виробів Черкаського науково-дослідного експертно-криміналістичного центру Міністерства внутрішніх справ України в усіх досліджуваних зразках насіння було встановлено відсутність $\Delta-9$-ТГК за методикою [4] в межах іiі чутливості.

Відповідно до методу № 1 [15] до попередньо гомогенізованих наважок насіння (зразки $\mathrm{A}_{1}$ i $\mathrm{B}_{1}$ ) масою по 500 мг кожна додавали по $4 \mathrm{~cm}^{3} 0,2$ н розчину калій гідроксиду $(\mathrm{KOH})$ в метанолі. Отримані суміші поміщали в ультразвукову ванну та екстрагували впродовж 30 хв., після чого проводили центрифугування для відділення нерозчинних домішок при 4000 об/хв. впродовж 10 хв. і фільтрували через складчастий паперовий фільтр. Далі проводили чотирикратне промивання фільтрату порціями гексану об'ємом $5 \mathrm{~cm}^{3}$. Верхній шар органічних сполук відкидали. Під час останнього промивання до гексану додавали

(C) С. В. Шкурдода, Т. В. Солодовнік, В. В. Пасічник, К. П. Король, Д. Ю. Шинкаренко, 2021 DOI: 10.24025/2306-4412.1.2021.230000 
$1 \mathrm{~cm}^{3}$ дейонізованої води для зменшення змішування гексану з метанолом. Верхній органічний шар відкидали. До розчину додавали $1,5 \mathrm{~cm}^{3} 1 \mathrm{M}$ розчину хлороводневої кислоти $(\mathrm{HCl})$ та проводили екстракцію $5 \mathrm{~cm}^{3} 10 \%$ (об./об.) етилацетату в гексані. Верхній органічний шар переносили у чистий скляний бюкс і випаровували в потоці теплого повітря. До сухого залишку додавали $1,0 \mathrm{~cm}^{3}$ етилацетату та переносили до віали 3 подальшим проведенням аналізу методом ГХ-МС.

Відповідно до методу № 2 до попередньо гомогенізованих наважок насіння (зразки $\mathrm{A}_{2}$ i $\mathrm{B}_{2}$ ) масою по 500 мг кожна додавали по $5 \mathrm{~cm}^{3}$ ацетонітрилу. Суміш поміщали в ультразвукову ванну та екстрагували впродовж 30 хв., після чого проводили центрифугування для відділення нерозчинних домішок при 4000 об/хв. впродовж 10 хв. та фільтрували через складчастий паперовий фільтр. Далі проводили трикратне промивання фільтрату порціями гексану об'ємом 5 cм³ $^{3}$. Нижній органічний шар об'ємом $5 \mathrm{~cm}^{3}$ переносили у чистий скляний бюкс і випаровували в потоці теплого повітря до об'єму $1 \mathrm{~cm}^{3}$. Отриманий розчин переносили до віали 3 подальшим проведенням аналізу методом ГХ-МС.

За методом № 3 до попередньо гомогенізованих наважок насіння (зразки $\mathrm{A}_{3} \mathrm{i}_{3}$ ) масою по 500 мг кожна додавали по $5 \mathrm{~cm}^{3}$ етанолу. Суміші поміщали в ультразвукову ванну та екстрагували впродовж 30 хв., а потім суміші переносили до морозильної камери $\left(-15^{\circ} \mathrm{C}\right)$ на 2 год. Далі проводили центрифугування для відділення нерозчинних домішок при 4000 об/хв. впродовж 10 хв. та фільтрували через складчастий паперовий фільтр. Фільтрат об'ємом $5 \mathrm{~cm}^{3}$ переносили у скляний бюкс і випаровували в потоці теплого повітря до об'єму 1 см $^{3}$. Отриманий розчин переносили до віали 3 подальшим проведенням аналізу методом ГХ-МС.

Сутність методу № 4 полягає в тому, що до попередньо гомогенізованих наважок насіння (зразки $\mathrm{A}_{4} \mathrm{i}_{4}$ ) масою по 500 мг кожна додавали по $5 \mathrm{~cm}^{3}$ етанолу та по $5 \mathrm{~cm}^{3}$ дейонізованої води. Суміш поміщали в ультразвукову ванну та екстрагували впродовж 30 хв., після чого її переносили до морозильної камери $\left(-15^{\circ} \mathrm{C}\right)$ на 2 год. Далі проводили центрифугування для відділення нерозчинних домішок при 4000 об/хв. впродовж 10 хв. та фільтрували через складчастий паперовий фільтр.

Фільтрат тричі екстрагували хлороформом порціями по $2 \mathrm{~cm}^{3}$. Хлороформні екстракти відділяли, переносили до скляного бюкса і випаровували в потоці теплого повітря. До сухого залишку додавали $1 \mathrm{~cm}^{3}$ етилацетату, переносили до віали 3 подальшим проведенням аналізу методом ГХ-МС.

Результати досліджень та їх обговорення. Аналізуючи отримані за методом № 1 результати для зразка $\mathrm{A}_{1}$, встановлено, що на хроматограмі досліджуваного екстракту без штучно внесеного $\Delta-9$-ТГК:

- спостерігаються піки досить значної інтенсивності, які відповідають за часом утримання Linoleic Acid (лінолева кислота) та Linoleic Acid methyl ester (метиловий естер лінолевої кислоти);

- спостерігаються піки середньої інтенсивності, які відповідають за часом утримання Palmitic Acid (пальмітинова кислота), Palmitic Acid methyl ester (метиловий естер пальмітинової кислоти), Stearic Acid (стеаринова кислота), Arachidonic Acid (арахідонова кислота) тощо;

- не виявлено піка речовини, мас-спектр якої було ідентифіковано як Dronabinol (дронабінол, тетрагідроканнабінол, ТГК, $\Delta$-9-ТГК) у межах чутливості проведеного методу дослідження.

Для досліджуваного екстракту зі штучно внесеною кількістю $\Delta$-9-ТГК (зразок $\mathrm{B}_{1}$ ), отриманого за методом № 1 (рисунок 1), виявлено:

- піки досить значної інтенсивності, що відповідають за часом утримання Linoleic Acid (лінолева кислота) та Linoleic Acid methyl ester (метиловий естер лінолевої кислоти);

- піки середньої інтенсивності, що відповідають за часом утримання Palmitic Acid (пальмітинова кислота), Palmitic Acid methyl ester (метиловий естер пальмітинової кислоти), Stearic Acid (стеаринова кислота), Arachidonic Acid (арахідонова кислота) тощо;

- пік середньої інтенсивності, що за часом утримання $(\mathrm{RT}=5,767$ хв.) відповідає речовині, мас-спектр якої ідентифіковано як Dronabinol (дронабінол, тетрагідроканнабінол, ТГК, $\Delta$-9-ТГК). 


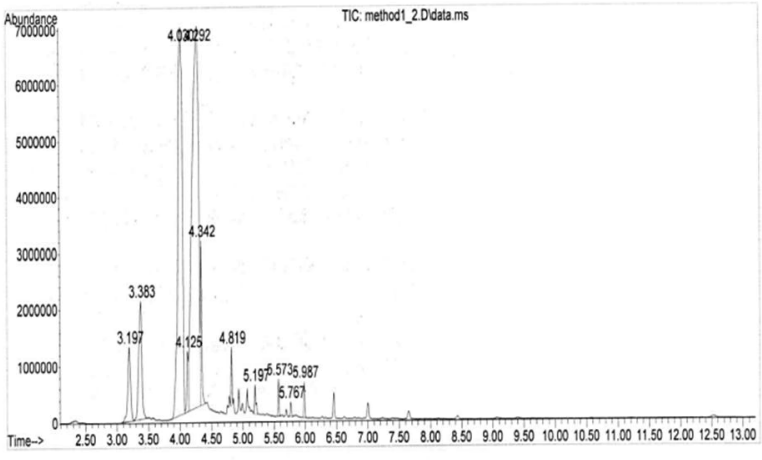

Рисунок 1 - Хроматограма, отримана при визначенні $\Delta$-9-ТГК за методом № 1

Аналізуючи отримані за методом № 2 для зразка $\mathrm{A}_{2}$ дані, встановлено, що на хроматограмі досліджуваного екстракту без штучно внесеного $\Delta$-9-ТГК:

- спостерігається пік досить значної інтенсивності, що відповідає за часом утримання Linoleic Acid (лінолевій кислоті);

- піка речовини, мас-спектр якої було б ідентифіковано як Dronabinol (дронабінол, тетрагідроканнабінол, ТГК, $\Delta$-9-ТГК), у межах чутливості проведеного методу дослідження не виявлено.

Для досліджуваного екстракту зі штучно внесеною кількістю $\Delta$-9-ТГК (зразок $\mathrm{B}_{2}$ ), отриманого за методом № 2 (рисунок 2), виявлено:

- пік досить значної інтенсивності, що відповідає за часом утримання Linoleic Acid (лінолева кислота);

- пік середньої інтенсивності, що за часом утримання (RT $=5,765$ хв.) відповідає речовині, мас-спектр якої ідентифіковано як Dronabinol (дронабінол, тетрагідроканнабінол,

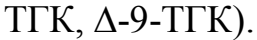

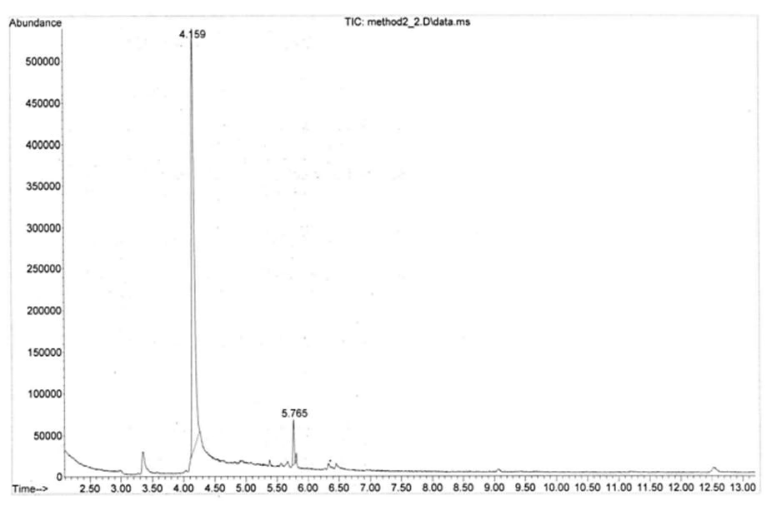

Рисунок 2 - Хроматограма, отримана при визначенні $\Delta$-9-ТГК за методом № 2
Аналізуючи отримані за методом № 3 для зразка $\mathrm{A}_{3}$ дані, встановлено, що на хроматограмі досліджуваного екстракту без штучно внесеного $\Delta$-9-ТГК:

- спостерігається пік значної інтенсивності, що відповідає за часом утримання Linoleic Acid (лінолева кислота);

- спостерігаються піки середньої інтенсивності, що відповідають за часом утримання Palmitic Acid (пальмітинова кислота), Stearic Acid (стеаринова кислота), gammaTocopherol ( $\gamma$-Токоферол), Campesterol (Кампестерол), Stigmasterol (Стігмастерол), gamma-Sitosterol ( $\gamma$-Сітостерол) тощо;

- піка речовини, мас-спектр якої було б ідентифіковано як Dronabinol (дронабінол, тетрагідроканнабінол, ТГК, $\Delta$-9-ТГК), у межах чутливості проведеного методу дослідження не виявлено.

Для досліджуваного екстракту зі штучно внесеною кількістю $\Delta$-9-ТГК (зразок $\mathrm{B}_{3}$ ), отриманого за методом № 1 (рисунок 3), виявлено:

- пік значної інтенсивності, що відповідає за часом утримання Linoleic Acid (лінолева кислота);

- піки середньої інтенсивності, що відповідають за часом утримання Palmitic Acid (пальмітинова кислота), Stearic Acid (стеаринова кислота), gamma-Tocopherol ( $\gamma$ Токоферол), Campesterol (Кампестерол), Stigmasterol (Стігмастерол), gamma-Sitosterol ( $\gamma$-Сітостерол) тощо;

- пік середньої інтенсивності, що за часом утримання (RT $=5,770$ хв.) відповідає речовині, мас-спектр якої ідентифіковано як Dronabinol (дронабінол, тетрагідроканнабінол, ТГК, $\Delta-9-\mathrm{TГК).}$

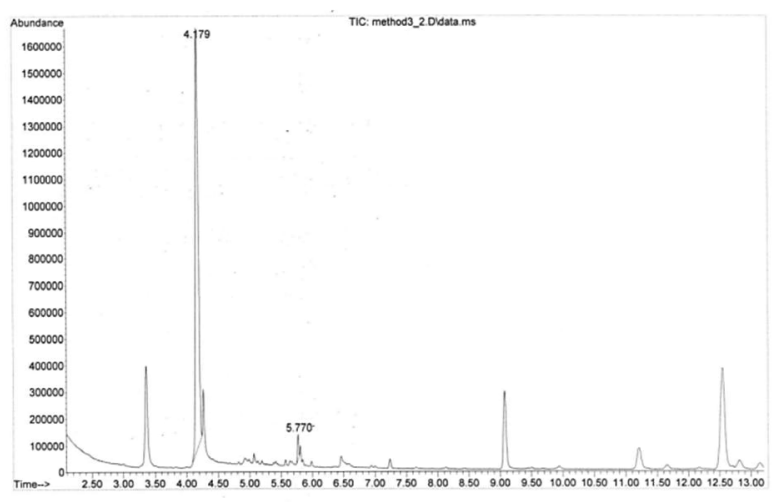

Рисунок 3 - Хроматограма, отримана при визначенні $\Delta$-9-ТГК за методом № 3 
Аналізуючи отримані за методом № 4 для зразка $\mathrm{A}_{4}$ дані, встановлено, що на хроматограмі досліджуваного екстракту без штучно внесеного $\Delta$-9-ТГК:

- спостерігається пік значної інтенсивності, що відповідає за часом утримання Linoleic Acid (лінолева кислота);

- спостерігаються піки середньої інтенсивності, що відповідають за часом утримання Palmitic Acid (пальмітинова кислота), Stearic Acid (стеаринова кислота), gammaTocopherol ( $\gamma$-Токоферол), Campesterol (Кампестерол), Stigmasterol (Стігмастерол) gammaSitosterol ( $\gamma$-Сітостерол) тощо;

- піка речовини, мас-спектр якої було б ідентифіковано як Dronabinol (дронабінол, тетрагідроканнабінол, ТГК, $\Delta$-9-ТГК), у межах чутливості проведеного методу дослідження не виявлено.

Для досліджуваного екстракту зі штучно внесеною кількістю $\Delta$-9-ТГК (зразок $\mathrm{B}_{4}$ ), отриманого за методом № 4 (рисунок 4), виявлено:

- пік значної інтенсивності, що відповідає за часом утримання Linoleic Acid (лінолева кислота);

- піки середньої інтенсивності, що відповідають за часом утримання Palmitic Acid (пальмітинова кислота), Stearic Acid (стеаринова кислота), gamma-Tocopherol $(\gamma$ Токоферол), Campesterol (Кампестерол), Stigmasterol (Стігмастерол) gamma-Sitosterol ( $\gamma$-Сітостерол) тощо;

- пік середньої інтенсивності, що за часом утримання ( $\mathrm{RT}=5,775$ хв.) відповідає речовині, мас-спектр якої ідентифіковано як Dronabinol (дронабінол, тетрагідроканнабінол,

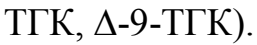

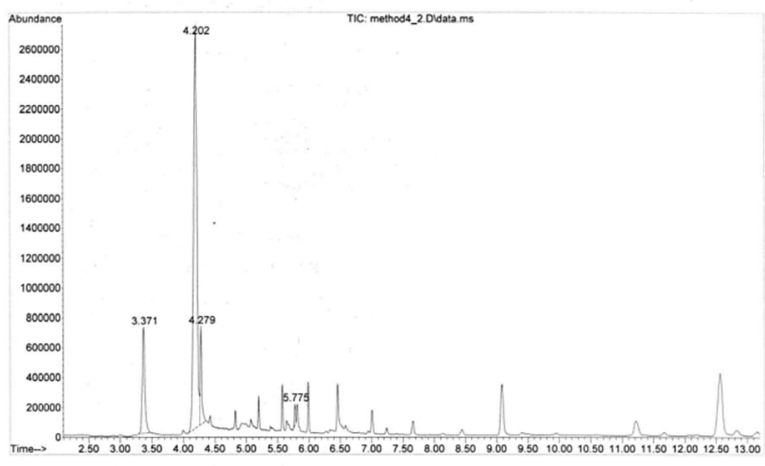

Рисунок 4 - Хроматограма, отримана при визначенні $\Delta-9$-ТГК за методом № 4
Авторами роботи було розроблено та апробовано методики пробопідготовки та екстракції, які є придатними для виявлення $\Delta$ 9-ТГК в незначних кількостях, насамперед у насінні конопель. Як видно 3 отриманих хроматограм, методика із застосуванням як екстрагента ацетонітрилу з наступним промиванням гексаном (метод № 2) найбільше відповідає поставленій меті дослідження, а саме виявленню $\Delta-9$-ТГК в незначних кількостях, насамперед у насінні конопель. Зазначений метод екстракції $\epsilon$ ефективнішим порівняно 3 методами 1, 3 й 4 для застосування у зв'язку 3 найменшою кількістю коекстрактивних речовин, виявлених на хроматограмі, насамперед жирів та продуктів гідролізу жирів, зокрема вищих карбонових кислот (насичених i ненасичених), які можуть завадити дослідженню.

Висновки. В результаті проведення комплексу експериментальних досліджень 3 пошуку ефективної методики якісного виявлення $\Delta-9$-ТГК в конопляному насінні методом рідинно-рідинної екстракції було встановлено, що всі чотири методи рідинно-рідинної екстракції загалом придатні для виявлення $\Delta$-9-ТГК в насінні конопель, а також характеризуються приблизно однаковою чутливістю до визначення $\Delta-9-$ ТГК в незначних концентраціях.

Дослідженнями також було доведено, що кожний метод відрізняється за кількістю коекстрактивних речовин, виявлених на хроматограмі, насамперед жирів та продуктів гідролізу жирів, зокрема вищих карбонових кислот (насичених і ненасичених).

Встановлено, що серед усіх чотирьох проведених методів пробопідготовки (екстракціï) для виявлення $\Delta-9$-ТГК метод № $2 \epsilon$ найефективнішим, легко відтворюваним та повністю відповідає меті дослідження у зв'язку 3 найменшою кількістю коекстрактивних речовин, виявлених на хроматограмі.

Доведено, що метод № 2 може бути рекомендованим для якісного визначення $\Delta-9$ ТГК в незначних концентраціях, у тому числі для його визначення у насінні конопель.

Результати проведених досліджень можуть бути використані для якісного й кількісного визначення $\Delta-9-$-ГК як у насінні, так і в продуктах харчування, виготовлених 3 насіння конопель.

Умовою цього є подальше дослідження 3 метою визначення межі детектування $\Delta-9$-ТГК

(C) С. В. Шкурдода, Т. В. Солодовнік, В. В. Пасічник, К. П. Король, Д. Ю. Шинкаренко, 2021 DOI: $10.24025 / 2306-4412.1 .2021 .230000$ 
(LOD) та межі кількісного виявлення $\Delta-9$-ТГК (LOQ), що необхідно для подальшої сертифікації зазначеної продукції та її експорту.

\section{Список використаних джерел}

[1] O. Aizpurua-Olaizola et al., "Evolution of the Cannabinoid and Terpene content during the growth of Cannabis sativa plants from different chemotypes", Journal of Natural Products, vol. 79, no. 2. pp. 324-331, 1964. doi: 10.1021/acs.jnatprod.5b00949.

[2] R. G. Pertwee, "Pharmacological and therapeutic targets for $\Delta^{9}$-tetrahydro-cannabinol and cannabidiol", Euphytica, vol. 140, no. 1-2, pp. 73-82, 2004. doi: 10.1007/s10681-004-4756-9.

[3] М. Д. Мигаль, І. Л. Кмець, та І. М. Лайко, Трихоми і канабіноїди конопель. До теорії селекції ненаркотичних сортів: монографія. Суми: ФОП Щербина I.В., 2017.

[4] С. В. Шкурдода, В.В. Пасічник, та К. П. Король, Якісне та кількісне визначення канабіноїдів у частинах рослин конопель методом хромато-мас-спектрометрії. Київ: ДНДЕКЦ МВС України, 2019.

[5] Г. Бойко, Г. Тіхосова, та А. Кутасов, "Технічні коноплі: Перспективи розвитку в Україні", Товари і ринки, № 1, с. 110-120, 2018.

[6] В. Г. Вировець та ін. Коноплі: монографія. Суми: Еллада, 2011.

[7] Qingling Wang, and Youling L. Xiong, "Processing, nutrition, and functionality of hempseed protein: A review", Comprehensive Reviews in Food Science and Food Safety, pp. 936-952, 2019.

[8] Н. А. Сова, "Технологія комплексної переробки насіння промислових конопель", автореф. дис. канд. техн. наук: спец. 05.18.02 "Технологія зернових, бобових, круп'яних продуктів і комбікормів, олійних і луб’яних культур", Херсон, 2019.

[9] J. C Callaway, "Hempseed as a nutritional resource: An overview", Euphytica, no. 140, pp. 65-72, 2004.

[10] J. D. House, J. Neufeld, and G. Leson, "Evaluating the quality of protein from hemp seed (Cannabis sativa L.) products through the use of the protein digestibilitycorrected aminoacid score method", Journal of Agricultural and Food Chemistry, no. 58, pp. 11801-11807, 2010.
[11] R. Russo, and R. Reggiani, "Variability in antinutritional compounds in hempseed meal of Italian and French varieties", Plant, no. 1, pp. 25-29, 2013.

[12] L. Lehmann, F. Sager, and R. Brenneisen, "Excretion of cannabinoids in urine after ingestion of cannabis seed oil", Journal of analytical toxicology, no. 21, pp. 373-375, 1997.

[13] N. Fortner et al., "Marijuana-positive urine test results from consumption of hemp seeds in food products", Journal of analytical toxicology, no. 21, pp. 476-481, 1997. doi: 10.1093/jat/21.6.476.

[14] R. E. Struempler, G. Nelson, and F. M. Urry, "A positive cannabinoids workplace drug test following the ingestion of commercially available hemp seed oil", Journal of analytical toxicology, no. 21, pp. 283-285, 1997. doi: 10.1093/jat/21.4.283.

[15] M. H. Justin et al., " $\Delta 9$-tetrahydrocannabinol content of commercially available hemp products", Journal of Analytical Toxicology, no. 32, pp. 428-432, 2008.

[16] G. M. Patwardan, M. D. Pundlik, and S. K. Meghal, "Dunnschichtchromatpgraphischer Nachweis von Haschischwirkstoffen in cannabis samen" ("A thin layer chromatographic method for the detection of resins in cannabis seeds"), Arch. Kriminol., no. 159, pp. 36-39, 1997.

[17] M. J. De Faubert Maunder, "A comparative evaluation of the delta-9-tetrahydrocannabinol content of cannabis plants", Journal of the Association of Public Analysts, no. 8, pp. 42-47, 1970.

[18] T. Matsunaga, H. Nagatomo, I. Yamamoto, and I. Yoshimura, "Identification and determination of cannabinoids in commercially available cannabis seeds", Eisei Kagaku, no. 36, pp. 545-547, 1990.

[19] G. M. Patwardan, M. D. Pundlik, and S. K. Meghal, "Gas-chromatographic detection of resins in cannabis seeds", Indian J. Pharm. Sci., no. 40, pp. 166-167, 1978.

[20] P. S. Fetterman, E. S. Keith, and C. W. Waller, "Mississippi-grown Cannabis sativa L.: Preliminary observation on chemical definition of phenotype and variations in tetrahydrocannabinol content versus age, sex, and plant part", J. Pharm. Sci., no. 70, pp. 12461249, 1971.

[21] T. Matsunaga, H. Nagatomo, I. Yamamoto, and H. Yoshimura, "Qualitative and quanti-

(C) С. В. Шкурдода, Т. В. Солодовнік, В. В. Пасічник, К. П. Король, Д. Ю. Шинкаренко, 2021 DOI: $10.24025 / 2306-4412.1 .2021 .230000$ 
tative analysis of cannabinoids in cannabis seeds", Hochudohu, no. 8, pp. 88-89, 1990.

[22] H. Mollenken, and H. Husmann, "Cannabinoid in seed extracts of Cannabis sativa cultivars", J. Int. Hemp Assoc., no. 4, pp. 73-79, 1997.

[23] Samir A. Ross, Zlatko Mehmedic, Timothy P. Murphy, and Mahmoud A. EISohly, "GCMS analysis of the total Ag-THC content of both drug- and fiber-type Cannabis seeds", Journal of Analytical Toxicology, no. 24, pp. 715-717, 2000.

[24] Кабінет Міністрів України (2000, трав. 06). Постанова № 770, Про затвердження переліку наркотичних засобів, психотропних речовин $i$ прекурсорів. [Електронний ресурс]. Режим доступу: https://zakon.rada.gov.ua/laws/show/7702000-\%D0\%BF\#Text.

\section{References}

[1] O. Aizpurua-Olaizola et al., "Evolution of the Cannabinoid and Terpene content during the growth of Cannabis sativa plants from different chemotypes", Journal of Natural Products, vol. 79, no. 2. pp. 324331, 1964.

doi: 10.1021/acs.jnatprod.5b00949.

[2] R. G. Pertwee, "Pharmacological and therapeutic targets for $\Delta^{9}$-tetrahydro-cannabinol and cannabidiol", Euphytica, vol. 140, no. 1-2, pp. 73-82, 2004. doi: 10.1007/s10681-004-4756-9.

[3] M. D. Myhal, I. L. Kmets, and I. M. Laiko, Trichomes and cannabinoids of hemp. To the theory of selection of non-narcotic varieties: monograph. Sumy: FOP Shcher-byna I.V., 2017 [in Ukrainian].

[4] S. V. Shkurdoda, V. V. Pasichnyk, and K. P. Korol, Qualitative and quantitative determination of cannabinoids in parts of cannabis plants by chromato-mass spectrometry. Kyiv: DNDEKTs MVS Ukrainy, 2019 [in Ukrainian].

[5] H. Boiko, H. Tikhosova, and A. Kutasov, "Technical hemp: Prospects for development in Ukraine", Tovary i rynky, no. 1, pp. 110120, 2018 [in Ukrainian].

[6] V. H. Vyrovets et al., Hemp: monograph. Sumy: Ellada, 2011. [in Ukrainian].

[7] Qingling Wang, and Youling L. Xiong, "Processing, nutrition, and functionality of hempseed protein: A review", Comprehen- sive Reviews in Food Science and Food Safety, pp. 936-952, 2019.

[8] N. A. Sova, "Technology of complex processing of industrial hemp seeds", Ph.D. abstract: spec. 05.18.02 "Technology of cereals, legumes, cereals and animal feeds, oilseeds and bast crops", Kherson, 2019 [in Ukrainian].

[9] J. C Callaway, "Hempseed as a nutritional resource: An overview", Euphytica, no. 140, pp. 65-72, 2004.

[10] J. D. House, J. Neufeld, and G. Leson, "Evaluating the quality of protein from hemp seed (Cannabis sativa L.) products through the use of the protein digestibilitycorrected aminoacid score method", Journal of Agricultural and Food Chemistry, no. 58, pp. 11801-11807, 2010.

[11] R. Russo, and R. Reggiani, "Variability in antinutritional compounds in hempseed meal of Italian and French varieties", Plant, no. 1, pp. 25-29, 2013.

[12] L. Lehmann, F. Sager, and R. Brenneisen, "Excretion of cannabinoids in urine after ingestion of cannabis seed oil", Journal of analytical toxicology, no.21, pp.373-375, 1997.

[13] N. Fortner et al., "Marijuana-positive urine test results from consumption of hemp seeds in food products", Journal of analytical toxicology, no. 21, pp. 476-481, 1997. doi: $10.1093 /$ jat $/ 21.6 .476$.

[14] R. E. Struempler, G. Nelson, and F. M. Urry, "A positive cannabinoids workplace drug test following the ingestion of commercially available hemp seed oil", Journal of analytical toxicology, no. 21, pp. 283-285, 1997. doi: $10.1093 /$ jat/21.4.283.

[15] M. H. Justin et al., " $\Delta 9$-tetrahydrocannabinol content of commercially available hemp products", Journal of Analytical Toxicology, no. 32, pp. 428-432, 2008.

[16] G. M. Patwardan, M. D. Pundlik, and S. K. Meghal, "Dunnschichtchromatpgraphischer Nachweis von Haschischwirkstoffen in cannabis samen" ("A thin layer chromatographic method for the detection of resins in cannabis seeds"), Arch. Kriminol., no. 159 , pp. $36-39,1997$.

[17] M. J. De Faubert Maunder, "A comparative evaluation of the delta-9-tetrahydrocannabinol content of cannabis plants", Journal of the Association of Public Analysts, no. 8, pp. 42-47, 1970. 
[18] T. Matsunaga, H. Nagatomo, I. Yamamoto, and I. Yoshimura, "Identification and determination of cannabinoids in commercially available cannabis seeds", Eisei Kagaku, no. 36, pp. 545-547, 1990.

[19] G. M. Patwardan, M. D. Pundlik, and S. K. Meghal, "Gas-chromatographic detection of resins in cannabis seeds", Indian J. Pharm. Sci., no. 40, pp. 166-167, 1978.

[20] P. S. Fetterman, E. S. Keith, and C. W. Waller, "Mississippi-grown Cannabis sativa L.: Preliminary observation on chemical definition of phenotype and variations in tetrahydrocannabinol content versus age, sex, and plant part", J. Pharm. Sci., no. 70, pp. 12461249,1971

[21] T. Matsunaga, H. Nagatomo, I. Yamamoto, and H. Yoshimura, "Qualitative and quanti- tative analysis ofcannabinoids in cannabis seeds", Hochudohu, no. 8, pp. 88-89, 1990.

[22] H. Mollenken, and H. Husmann, "Cannabinoid in seed extracts of Cannabis sativa cultivars", J. Int. Hemp Assoc., no. 4, pp. 73-79, 1997.

[23] Samir A. Ross, Zlatko Mehmedic, Timothy P. Murphy, and Mahmoud A. EISohly, "GCMS analysis of the total Ag-THC content of both drug- and fiber-type Cannabis seeds", Journal of Analytical Toxicology, no. 24, pp. 715-717, 2000.

[24] Cabinet of Ministers of Ukraine (2000, May 06). Resolution no. 770, On approval of the list of narcotic drugs, psychotropic substances and precursors. [Online]. Available: https://zakon.rada.gov.ua/laws/show/ 770-2000-\%D0\%BF\#Text.

S. V. Shkurdoda ${ }^{1}$, head of the research department of materials, substances and products, e-mail: sergeyshkur@yahoo.com

T. V. Solodovnik ${ }^{2}$, Ph.D., associate professor, e-mail: solodovniktetana@gmail.com

V. V. Pasichnyk ${ }^{1}$, deputy head of the research sector,

K. P. Korol ${ }^{1}$, head of the research sector,

D. Yu. Shynkarenko ${ }^{1}$, chief forensic expert

${ }^{1}$ Cherkasy Research Forensic Center of the MIA of Ukraine

Pasterivska st, 104, Cherkasy, 18000, Ukraine

${ }^{2}$ Cherkasy State Technological University

Shevchenko blvd, 460, Cherkasy, 18006, Ukraine

\section{METHODS FOR DETERMINATION OF $\triangle$ 9-TETRAHYDROCANNABINOL CONTENT IN SEEDS OF HEMP BY GAS CHROMATOGRAPHY METHOD: ANALYSIS AND SCIENTIFIC JUSTIFICATION}

Cannabis (Cannabis sativa L) has been an important part of the well-being of the population for many centuries. This plant is a bast and oilseed crop that is characterized by specific biological and unique consumer properties. However, hemp plants also have medicinal and narcotic properties. Cannabis plants can excrete secretions that contain cannabinoids. The psychotropic effect of the narcotic drug cannabis is the result of the complex action of all cannabinoids, although only some of them have a psychotropic effect in its pure form. These include, first, delta-9-tetrahydrocannabinol (4-9THC), which has a major psychotropic effect and is able to selectively bind to cannabinoid receptors in certain brain structures. In this regard, the development of simple and effective methods of detection ( $\Delta-9-T H C)$ in hemp plant seeds is an urgent issue.

The article considers the analysis of existing methods of liquid-liquid extraction of $\Delta-9-T H C$ from hemp seeds with their subsequent approbation and improvement for separation of interfering fractions, first of all fats (oils), and with the subsequent identification of $\Delta-9-T H C$ by gas chromatomass spectrometry with mass-selective detection. Some methods of liquid-liquid extraction of hemp seeds and comparison of the obtained results are given. To solve this goal, seeds collected from technical hemp of the Glyana variety, cultivated from plants of the genus of hemp for industrial purposes, allowed by the legislation of Ukraine, are collected from varieties of hemp plants in dried straw whose content of $\Delta-9-T H C$ does not exceed 0.08 percent. It has been found that the method with the use of acetonitrile as an extracting, followed by washing with hexane, most meets the goal of the study,

(c) С. В. Шкурдода, Т. В. Солодовнік, В. В. Пасічник, К. П. Король, Д. Ю. Шинкаренко, 2021 DOI: $10.24025 / 2306-4412.1 .2021 .230000$ 
namely to detect $\Delta-9-T H C$ in small quantities, especially in hemp seeds. This method of extraction is best suited due to the lowest amount of co-extractives found on the chromatogram, primarily fats and fat hydrolysis products, namely higher carboxylic acids (saturated and unsaturated), which may interfere with the study. These studies can be further used to quantify $\Delta-9-T H C$ in hemp seeds and foods made from hemp seeds, followed by the detection limit (LOD) and the limit of quantification (LOQ) of the substance, which is necessary for further certification of these products and exports. The obtained research results allow to determine the presence of $\Delta-9-T H C$ in hemp seeds and food products made from hemp seeds.

Keywords: $\triangle 9$-THC, technical hemp, hemp seeds, cannabinoids, extraction, gas chromato-mass spectrometry.

Стаття надійшла 15.02.2021

Прийнято 12.03.2021 